371.3:811.111'24

https://doi.org/10.18485/bells.2019.11.4

\author{
Lia Efstathiadi* \\ School of English \\ Aristotle University of Thessaloniki \\ Thessaloniki, Greece
}

\title{
EARLY FOREIGN LANGUAGE LEARNING: INTENSIVE EXPOSURE, VOCABULARY DEVELOPMENT AND THE COGNITIVE SKILLS INVOLVED
}

\begin{abstract}
This report concerns vocabulary development and its cognitive underpinning in 49 young Greek learners ( $M=7$ years, 8 months), after two years of intensive exposure to L2 English. The data come from an experimental school for the teaching of English in Thessaloniki, implementing innovative teaching methodologies. Testing took place in Grade 2, when participants had received significant L2 exposure (approximately 300 hours). We measured L2 vocabulary (comprehension, production) and working memory (WM), the phonological store in particular, since this shares close links with early L2 vocabulary development (Gathercole \& Alloway 2008). Due to the demanding nature of the L2 communicative classroom regarding attention resources, we also investigated the role of the central executive of WM in early FL vocabulary development.
\end{abstract}

Keywords: early FL vocabulary development, CLIL, phonological short-term memory, central executive

E-mail address: economid@enl.auth.gr 


\section{Introduction - Setting the context}

Over the past thirty years learner performance and differential success in SLA and FL learning have been attributed to various contributing factors (for a review see Dörnyei 2005; Ehrman, Leaver \& Oxford 2003) such as instructional context (Wesche 1981), age at which instruction begins (Johnson \& Newport 1989), motivation (Dörnyei 2005; Dörneyi \& Skehan 2003), personality traits (Gardner 1990), FL aptitude (Carroll 1981). More recently, the interest of academia has shifted to executive functions and their role in FL learning.

This article forms part of longitudinal research ${ }^{1}$ with a cognitive orientation that explores the involvement of various mental skills in L2 vocabulary development and narrative writing. The present study examines early FL learning (EFLL) taking place in a formal context, i.e. a partial immersion school offering optimal conditions (qualified teachers, input flood, small size of FL classes) and bilingual education to its students. It investigates the outcome of a two-year period of intensive L2 exposure in terms of vocabulary growth (comprehension and production in oral discourse) and seeks to explore whether, apart from the phonological store of working memory (see section 1.3.1), there are other cognitive skills underpinning the early (between the ages of 6 and 8) learning of an additional language.

In the following sections, we sketch out the theoretical framework of the study, touching upon issues such as the age factor and the early introduction of a FL in a formal setting, the intensification of FL programmes through the employment of teaching approaches such as CLIL (Content and Language Integrated Learning), and finally the contribution of cognitive skills, in particular WM, to the process of starting learning a FL very early.

\subsection{Early Foreign Language Learning (EFLL)}

The age factor has been at the heart of a long-standing debate in SLA literature (for a review see Singleton \& Ryan 2004) and constitutes one of the crucial variables that can affect the learning outcome, in a SL or a FL setting. In a discussion of the age effect on FL learning, Muñoz (2010) argues that this has been primarily studied in natural settings, i.e. in cases

1 The same cohort of students was tested in Grades 1, 2 and 6 of primary school. 
of early bilingualism where children learn their two languages at home and at school or in cases of immigrants, whose proficiency level in the TL is examined with respect to age of onset (i.e. arrival in the L2 community). In such studies the focus rests on the comparison between younger vs. older starters, with frequently contradictory findings emerging as to the language aspects each age group may exhibit superiority in (Singleton \& Ryan 2004). To resolve the conflict, Krashen, Long and Scarcella (1982) introduced the ideas of rate of learning and eventual success. On the one hand, older starters seem to be faster and more efficient learners in the short run because of their explicit learning capacities and cognitive maturity (Cenoz 2003; García Lecumberri \& Gallardo 2003; García Mayo 2003; Muñoz 2003, 2010), advanced conversational skills (Krashen 1985), or more sophisticated learning strategies (Oxford 1989). On the other hand, younger starters demonstrate a superior level of performance in the long term, mainly because of their low affective filter (Krashen 1985) and lower inhibition (McLaughlin 1984), the optimal conditions of learning they enjoy (Bialystok 1997; Pinter 2011) and the significant TL exposure they receive over time (Krashen, Scarcella \& Long 1982; Singleton \& Ryan 2004).

However, as Muñoz (2010) argues, the ultimate attainment advantage of the early start found in natural settings has been credited to a quite different setting, the FL one, even though evidence to support such a claim is scarce. Singleton and Ryan (2004) and Muñoz (2010) suggest that in a typical FL classroom setting, the superior ultimate advantage of early starters will take much longer to emerge because FL learners are part-time learners and the FL classroom is a low input level context: access to the TL outside the classroom is very limited and children do not receive enough contact hours to catch up in the long run (Pinter 2011). This makes the investigation of long-term benefits a tedious enterprise and explains the scarcity of such studies. On these grounds, Muñoz (2006, 2010) and Johnstone (2009) questioned the earlier the better view in all respects and suggested that early FL learning may be advantageous over time if various conditions are met, a representative sample of which are the following: a) young learners are provided with massive L2 exposure, b) they follow intensive L2 courses from one educational cycle to the next (primary school, junior and senior high school), and c) they are given plenty of opportunities to use the L2 in meaningful ways. One of the latest teaching approaches that may intensify FL programmes and provide learners with 
additional FL contact is CLIL, with the balanced integration of the content of another school subject (e.g. History) and of the FL in one school hour.

\subsection{Content and Language Integrated Learning (CLIL)}

Johnstone (2009) believes that CLIL programmes may help maximise the key variables of time and intensity and yield impressive linguistic and content outcomes, as they help learners become fluent and confident L2 users (Mihaljevic Djigunovic 2009; Nikolov \& Mihaljevic Djigunovic 2006). Since the 1990s, such programmes have become more and more commonplace in Canada, the Basque country, and Europe (Dalton-Puffer 2008; Eurydice Report 2012) because they lend themselves to naturalistic FL learning. Most of the learning is implicit and incidental and does not require explicit language instruction (Mattheoudakis, Alexiou \& Laskaridou 2014). In this sense, these programmes constitute a form of bilingual education and as such they are expected to carry at least some of the advantages of bilingualism and bilingual education (Cummins 1984). The experimental school this study was conducted in has introduced CLIL in the last grades of primary education since 2010 and as such it constitutes an example of a bilingual setting (see section 2.1).

As already mentioned, the study has a cognitive orientation. So far, EFLL research has investigated mostly the linguistic and affective gains of this enterprise rather than the cognitive ones (García Lecumberri \& Gallardo 2003; Mihaljevic Djigunovic \& Krevelj 2009; Muñoz 2010; Nikolov 2009a, b). To fill the gap, the present study examines the cognitive processes involved in the earliest stages of FL learning, between the ages of 6 and 8. In particular, it examines the relation between Early Foreign Language Learning (EFLL) and Working Memory (WM) which is one of the executive functions that emerges early in life (Beveridge, Jarrold \& Pettit 2002; Wiebe et al. 2011) and is closely connected to academic achievement (St. Clair-Thompson \& Gathercole 2006).

\subsection{Executive functions}

In recent years, scientific research has been exploring the link between executive functioning and FL learning. The three most frequently researched executive functions with respect to adults (Miyake et al. 2000) and children 
(Lehto et al. 2003; Monette, Bigras \& Guay 2011) are Working Memory, Inhibition and Shifting (for a review see Sawyer \& Ranta 2001), due to their close relevance to L1 acquisition and L2 learning (Andersson 2010). This study concentrates on and further explores the contribution of various constituents of Working Memory to early FL learning.

\subsubsection{Working Memory and FL learning}

Working memory is the human flexible capacity to store and manipulate information in real time and one of the cognitive processes which the learning and use of a FL draws on (Baddeley 2003; Gathercole \& Alloway 2008; Gathercole et al. 1992). It is a fragile system of limited capacity, regarding the amount of information that can be held before it is lost and the amount of time this material is available for further processing. Its capacity increases between the ages of 4 and 14, exhibiting a two- to three-fold expansion, while individual differences in capacity may have immediate consequences on children's cognition, L1 acquisition and L2 learning (Gathercole 1998).

Currently, the most influential model of WM is that of Baddeley and Hitch $(1974)^{2}$. According to this model, the central executive or complex WM combines storage and processing functions; it is a modality-free and limited in capacity system that performs a range of higher order cognitive operations such as directing attention, planning actions, solving problems, reasoning logically, etc. (Kimberg, D'Esposito \& Farah 1997). It also organises and monitors all WM operations, allocating cognitive resources and integrating information from long-term memory (LTM) and WM sub-systems: the phonological loop, the visuo-spatial sketchpad and the episodic buffer (Baddeley 1986, 1996, 2000). The loop or phonological short-term memory (PSTM) encodes, maintains and processes verbal material (Baddeley, Gathercole \& Papagno 1998). It consists of a shortterm phonological store that holds material in a phonological code which, if not rehearsed sub-vocally, decays within 1.5-2 seconds. It can also register visual information in the store, if this is silently articulated (Baddeley 2003; Sáfár \& Kormos 2008). Children engage in such conscious and consistent rehearsal after the age of 7 , which explains why there is a rapid increase of PSTM capacity after that age (Gathercole \& Pickering 2000a, b; Gathercole et al. 2004). The visuo-spatial sketchpad stores material in terms of visual

$2 \quad$ See also Baddeley (1986, 2003). 
and spatial features while the episodic buffer serves as an intermediary between the other WM stores and LTM (Dörnyei 2005), combining visual and verbal information into coherent episodes that are then sent to the LTM to be linked to existing representations (Alloway et al. 2004; Nevo \& Breznitz 2011).

The contribution of PSTM is most critical at the early stages of vocabulary learning (Mackey et al. 2002) in the L1 (Adams \& Gathercole 1996; Baddeley 1986; Gathercole \& Adams 1994; Gathercole \& Baddeley 1993; Gathercole et al. 1992) and the L2, in children and adults (Baddeley, Gathercole \& Papagno 1998; Cheung 1996; Gathercole \& Adams 1994; Gathercole \& Baddeley 1993; Masoura \& Gathercole 1999; Maбoúpa,

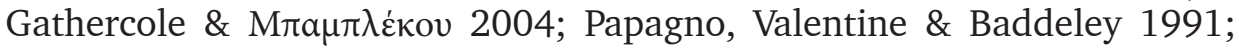
Service 1992). Also, the phonological store of WM facilitates general school achievement and fluent speech (Alloway \& Alloway 2010; Gathercole, Brown \& Pickering 2003; Gathercole \& Pickering 2000a, b; Gathercole et al. 2004; Kormos \& Sáfár 2008; St. Clair-Thompson \& Gathercole 2006) and improves comprehension, reading and listening abilities (for a review

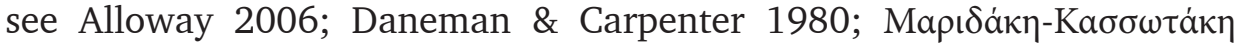
1998; Maridaki-Kassotaki 2002).

\subsection{The research question of the study}

There is abundant evidence on the predictive role of the phonological loop in L1 acquisition and L2 vocabulary learning. Nevertheless, Muñoz (2010) argues that these are two different processes in many respects. For one thing, FL learners are at a disadvantage when compared to L1 acquirers (Randall 2007); unlike L1 processing that is UG-driven (Bley-Vroman 1990; Chomsky 2005), FL processing is slower, less automated and more effortful, especially in the earliest stages (Andersson 2010; Wattendorf \& Festman 2008). Today more than ever before, with the implementation of innovative teaching methods and the increased interaction taking place in the FL classroom, learners need to make sense of large amounts of aural data that pose heavy processing demands on both their PSTM and attentional resources (Mackey et al. 2002; Sáfár \& Kormos 2008). WM is the "mental workspace" (Gathercole \& Alloway 2008: 16) where this conscious, directed and targeted processing of key language patterns takes place before these manage to enter LTM (Randall 2007). 
The instructed setting of the study is one such case: it is a partial immersion school that offers increased contact with English from the first year of L2 schooling; therefore, the idea of investigating whether the central executive (=the mechanism of WM that controls attention) is also involved in the early learning of novel vocabulary was viewed as an interesting challenge. The research question posed is the following:

Apart from the critical contribution of the phonological loop, does the central executive of WM also play a role at the earliest stages of learning novel vocabulary in the FL?

We expect participants to do equally well in the tasks that tap their phonological store and complex WM for two reasons: a) they are still building up their L1 vocabulary and are thus very much dependent upon their phonological loop to do so; although previous research indicates its close link to L1 acquisition and L2 learning up to 5 (Masoura \& Gathercole 1999) there is evidence (Service 1992) suggesting this can even stretch up to the age of $11-12$, b) Schmidt's theory of noticing and attention emphasises the key role of attended processing in the establishment of "new or modified knowledge, memory, skills, and routines" (2001: 29). In today's communicative classrooms young learners are constantly exposed to and overwhelmed by large amounts of input (Hummel \& French 2010; Robinson 2002). However, their information-processing capacity is limited (McLaughlin 1990, as cited in Ellis 2003: 390) and for any FLL to occur, young learners need to employ their attentional resources to the maximum to sort through the massive amounts of input encountered, "tune in" only what is relevant to the occasion and "tune out" the rest (Gass \& Mackey 2007: 186). As the central executive is the mechanism of WM responsible for the allocation of cognitive resources, we expect this to also play a key role in the process.

\section{The methodology of the study}

\subsection{The school}

The data form only part of the findings of longitudinal research exploring the involvement of various cognitive skills in L2 vocabulary development and narrative writing. The present study was carried out at the end of the 
second year of FL schooling to ensure that students had received significant L2 exposure (approximately 300 hours).

The primary school of this study is experimental for the teaching of English as a FL (EFL) (Mattheoudakis, Alexiou \& Laskaridou 2014). It introduces EFL from Grade 1 with five 45-minute lessons per week while these increase to eight from Grade 3 to Grade 6. This is a unique case in Greece as all mainstream schools introduce English from Grade 1 with one hour per week, which increases to three in the last four grades. Throughout the study English was taught by four highly specialised English teachers who collaborated very closely with each other. The school implements various teaching methods, some of which are Asher's (1982) Total Physical Response (TPR), Krashen and Terrell's Natural Approach (1983), Communicative Language Teaching (CLT), Task-based learning (TBL), Content and Language Integrated Learning (CLIL). All encourage the joint involvement of receptive and productive language since "both qualify equally as examples of practice" (Bialystok 1981: 25) and associate with the long-term retention of new linguistic material, a better understanding of novel utterances and the development of positive attitudes in learners towards language learning (Ellis 1994). The first two methodologies were implemented in Grades 1 and 2 as the school places emphasis on learner fluency and "oral competency in communication" (Terrell 1977: 326) and supports the development of listening and speaking skills in the first two years of schooling. One of its priorities is to help young learners build up a basic vocabulary, i.e. words, expressions, lexical knowledge salient to their life experiences and lay the foundations for future learning in ways that are both fun and pleasant. Through TPR the students are engaged in play-like activities that help them best develop their comprehension skills before the emergence of oral production (Lundberg \& Lindgren 2008, as cited in Nikolov \& Mihaljevic Djigunovic 2011). By means of the Natural approach they learn to interact in the FL via real communicative episodes embedded in a functional-notional syllabus that contains a series of topics, all relevant and of interest to them (see section 2.3.3), supplemented by games, tasks and other play-like activities that provide them with comprehensible FL input (Krashen 1985). 


\subsection{The participants}

All participants were Greek speakers, living in the same low to middleclass neighbourhood in the western part of Thessaloniki. The exclusionary criterion applied upon recruitment was that of monolingualism: bilingual and trilingual children or children with previous knowledge of English were excluded to avoid any confounding effect the additional language(s) might have on their English performance. The 49 informants (23 boys and 26 girls) came from three Grade 2 classes. Their mean age, standard deviation and range were the following: $M 7$ years, 8 months; SD 3 months; range: 7 years, 2 months to 8 years, 2 months.

Due to the young age of the participants, informed consent was obtained from the parents. Informants were located by means of a questionnaire and a letter distributed at the beginning of Grade 1 (via the school principals and teachers) to the students' parents/guardians. The letter explained the purpose of the research and emphasised that participation was optional, participants would be seen in hours falling outside the school's core program (i.e. Greek language, English language, Mathematics) and all data would be codified to ensure confidentiality. Twenty-one students were excluded because parental consent was not obtained or because they were not monolingual.

\subsection{The testing procedure and the tools used}

Informants were seen twice: at the beginning of Grade 1 we tested their L1 verbal intelligence and matched them for their native skills, according to the Linguistic Coding Hypothesis of Sparks and Ganschow (1991) these serve as the foundation for FL learning. We used the relevant sub-tests (vocabulary, metalinguistic concepts) of the two versions of the standardised Diagnostic Test of Verbal Intelligence (DVIQ) (Stavrakaki \& Tsimpli 2000) to assess in oral discourse (comprehension, production) their linguistic abilities in L1. DVIQ I addresses pre-schoolers while DVIQ II is designed for school-age children (ages 6.5 - 9.5). We ran DVIQ I because in Grade 1 some children fell on the borderline (6-6.5 years of age).

Before the end of Grade 2 participants were seen in two sessions; we examined the capacity of the phonological loop (PSTM) and the central executive (CWM) and their FL vocabulary, with regard to oral comprehension and production. They were tested individually in a quiet 
room on the school premises. Each testing session lasted approximately 20 minutes.

\subsubsection{Measures of PSTM}

The phonological loop was tested via the forward digit span test and two non-word repetition ones. In the forward digit span and recall test (Wechsler 1991) participants listened to series of digits (one digit per second) which they had to repeat in the same order. Presentation began with two digits in a series; two trials were presented at each level of difficulty. With a correct report of the sequence, the length of the next was increased by one digit. Level of difficulty gradually increased, reaching a maximum of nine digits in eight trials. The test was discontinued when both trials at a given level were incorrectly recalled. All successful responses were taken into account

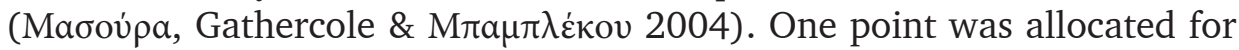
every successful response and half a point for a partially given correct response (right digits, wrong order). Maximum total score: 16 points.

Nonword repetition tasks involve the spoken presentation of artificial, void of meaning words, conforming to the phonotactics of a language. Nonword repetition is a reliable measure of PSTM capacity (Baddeley, Thomson \& Buchanan 1975) and a good predictor of vocabulary learning and other language skills during the early school years (Gathercole \& Adams 1994; Gathercole \& Baddeley 1993; Gathercole et al. 1992; for a review see Baddeley, Gathercole \& Papagno 1998). Nevertheless, what is documented is that nonword repetition tasks yield stronger relations to vocabulary scores than digit span ones (Gathercole 1999) due to the lexical unfamiliarity of the items. In this sense, they are much closer to the situation the FL learner faces in the beginning, where all verbal material is novel (Baddeley 2003; Baddeley, Gathercole \& Papagno 1998).

The two tasks used were: a) The Children's Test of Nonword Repetition (Gathercole \& Baddeley 1996), hereafter Nonce_Eng. and b) The Test of Nonword Repetition for Greek-speaking children (MaridakiKassotaki 1998), hereafter Nonce_Gr. Each consists of 40 nonwords which were auditorily presented to the informants. They listened to the words once and had 5 seconds to repeat each with full accuracy (all phonemes correct). Responses were recorded, coded and scored by the two native speakers (Greek, English) involved in the test. Each nonword correctly repeated was given a point; phonological deviations from the target form 
(addition, deletion, or phoneme replacement) were valued as incorrect and got no point (Archibald \& Gathercole 2006). When it was obvious that some children tended to misarticulate certain phonemes consistently, answers that contained these specific phonemes were scored as correct

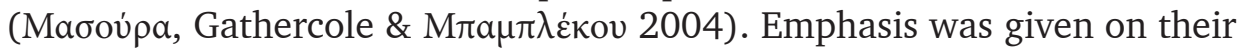
ability to reproduce the sounds as accurately as possible and not on their ability to mimic the English pronunciation as such. Maximum total score in either test was 40 points.

\subsubsection{Measures of CWM}

The capacity of complex WM (or the central executive) was tested by the Backwards digit recall task (Wechsler 1991) and a Listening and Recall test based on the one originally developed by Daneman and Carpenter (1980). Both tasks combine processing with concurrent storage.

a) The backwards digit span task: The test employs the same procedure as the forward condition in all respects except that participants are required to recall the spoken digits in the reverse order (Alloway \& Alloway 2010; Gathercole 1999; Nevo \& Breznitz 2011). The transposition of order requires the involvement of executive-attention resources (St. Clair-Thompson 2010) and imposes a substantial WM load on both the central executive and the phonological loop (Gathercole 1999; Kormos \& Sáfár 2008). Two practice trials were given to ensure participants understood the concept of reverse. There is a maximum of eight digits in overall seven trials. The test was run and scored the same way as in the forward condition. Maximum total score: 14 points.

b) The Listening span and Recall task: The task is a dual measure of WM for language (Baddeley 1996). The test requires the active maintenance of information in the face of simultaneous processing and interference and thus recruits executive attentioncontrol to combat interference (Conway et al. 2005). The task used is a modified version of the listening span test administered by Xpvбoxóov (2006) and requires the recall of semantically and phonologically unrelated words ${ }^{3}$. The test consists of six difficulty levels. Participants were told they would be presented with increasingly longer sets of sentences. One practice trial was given at

3 The list was designed by Tsimpli and Peristeri (personal communication). 
the one-sentence level, to familiarise them with the task demands. On each trial, they listened to a series of sentences, judged their veracity and then recalled the lexically unrelated words at the end of each set. Permission to go to the next level was granted only when four (not necessarily consecutive) correct trials were given within each level. In all statistical analyses, we took into account the participants' ability to correctly recall the word (i.e. storage capacity). Irrespective of performance on the semantic evaluation of the sentence, one point was given for every correctly recalled word. With four such cases in a level, six points were assigned to participants. To be credited with a point in levels 2, 3 and 4, they had to correctly recall a corresponding number of 2,3 or 4 words in each set.

\subsubsection{The English Vocabulary Test}

FL vocabulary was assessed with two measures examining oral skills (receptive, productive) (see Appendices 1 and 2 for sample slides). A pilot test was administered to eight students, to see whether the two subtests designed were easy, difficult or confusing and accordingly make the necessary modifications. Half of them were valued as high achievers by their English teachers, while the other half was the low achievers group. The pilot tests consisted of 5 items for every skill, 10 in total. None of these items appeared in the experimental test that followed. Instructions on the task were given in Greek.

The test was designed for the purposes of this research. The two subtests measured the knowledge gained during the first two years of the learners' FL schooling; thus, the material used was based on the school curriculum of Grades 1 and 2. Among the short stories or songs that learners had been exposed to during the two years were Winnie in Winter, Itsy Bitsy Spider, Goldilocks and the three bears, Hetty and the lion, Five little squirrels, Meg and Mog, etc. What follows is only a selection of the thematic fields covered in Grades 1 and 2 in the curriculum that refer to children's environment at home, outside the home and in school: family, friends, feelings, main numerals, the school, clothes, body parts, animals, the four seasons, Christmas, main colours, food, means of transportation, sports, as well as action verbs such as stand, sit, walk, turn around found in lexical rote-learned chunks of high frequency such as Point to (your ears), 
Sit down, or formulaic expressions such as How are you? I' $m$ fine, thanks, etc. The two tests were carefully designed to tap into the same thematic fields and tested whether participants could recall and produce a number of nouns (Szpotowicz 2010), action verbs (in the present progressive form), and adjectives they had been taught (Okalidou et al. 2011).

The receptive task was implemented first and comprised 15 slides. Children were asked to point to the picture that was being named (e.g. Point to the yellow pencil) or to do exactly what they were told (e.g. Show me your fingers). A digital stopwatch was used to record the time each needed to complete the test. For each individual a scoring sheet was kept on which we recorded their responses (correct, incorrect, not given) and the duration of the test (minutes, seconds).

The students' production was tested second. 15 slides displayed a number of different objects, actions, etc. The researcher asked 15 questions and tried to elicit as many answers as possible, with the help of the pictured objects or actions in the slides. 11 questions elicited a corresponding number of individual words, each credited with one point (e.g. What is this? A horse); the other four elicited chunks of words (e.g. Where is the boy sitting? On the bed) that were awarded 2 points each.

\section{Findings - Discussion}

We examined the learners' vocabulary performance with regard to their overall achievement (aggregate score: FL_Voc_Total) and we also measured separately comprehension and production. First we ran correlation analyses to explore the relations between the measures and then we conducted regression analyses to define the direction of causality; these would help us answer our research question. Table 1 below displays the descriptive statistics:

[Table 1: Descriptive Statistics - Mean and Standard Deviation (SD)]

\subsection{Performance in the FL vocabulary test}

a) FL_Receptive: Maximum score for this test was 15. The scores of the participants were distributed in three categories: a) those 
below the median quartile (37), b) the scores between the median and lower limit of the upper quartile (8-11; M-Q3 range hereafter), and c) those of the upper quartile (12-15). Figure 1 illustrates learner performance with respect to time duration and score, with each cycle representing one case.

[Figure 1: FL_Receptive: Time duration and score]

What becomes clear is that 34 students (69.4\%) scored in the upper quartile, 11 students (22.4\%) scored in the M-Q3 range and 4 students (8.2\%) scored below the median quartile.

b) FL_Productive: Maximum score for this test was 19. The scores were also distributed in three categories: a) those below the median quartile (39), b) the scores of the M-Q3 range (10-14), and c) those above the upper quartile (15-19). Figure 2 illustrates participants' performance in terms of score and time duration:

[Figure 2: FL_Productive: Time duration and score]

Figure 2 shows that only 16 students (32.7\%) scored in the upper quartile, 18 students (36.7\%) scored in the M-Q3 range and 15 students (30.6\%) scored below the median quartile.

The findings suggest that FL production was more difficult than comprehension. Of the $69.4 \%$ of the students who scored above the upper quartile in the receptive test, only $32.7 \%$ scored equally high in the productive. The difficulty students experienced was also reflected in the time required to complete the task. While they finished the productive test in a range of 100 to 363 seconds, they needed almost half this time for the receptive task (overall range: $60-198$ seconds).

c) Participants' combined performance in the two FL skills

Table 2 below shows the combined performance of participants in the two tests. What appears in bold, marks the number of students whose performance did not mark any difference (i.e. they performed equally poor, average, or good) in the two tests: 4 scored below median, 2 scored in the M-Q3 range, while 16 students scored above the upper quartile.

[Table 2: Participants' combined performance in the two FL tests]

Of the 11 students that scored in the M-Q3 range in the receptive test, 9 scored worse (below the median quartile) in the productive test. Also, of 
the 34 students that scored above the upper quartile in the receptive test, 2 students scored below median and 16 scored in the M-Q3 range in the productive test. The chi-square analysis revealed a statistically significant difference in learners' performance between the two tests, i.e. between the cases that did not manage to go to a higher quartile with those that actually scored significantly worse in the productive test: $\chi^{2}=33.051$, $d f=4, p<.001$.

The findings confirm previous studies (Lundberg \& Lindgren 2008, as cited in Nikolov \& Mihaljevic Djigunovic 2011) on early FL vocabulary learning. With meaning-focused interaction, spontaneous production emerges very slowly in the first two years and substantial time is needed before learners develop creative and fluent speech with reasonable accuracy and breadth (Blondin et al. 1998). Fall-backs have been reported for both comprehension and production after the first year of FL schooling, with development in the first year being faster than in the second. These have been attributed to the small amount of time spent on English (1-4 hours per week), the different didactic approaches adopted (Goorhuis-Brouwer \& De Bot 2010) and/or the teachers' frequent code-switching between the native language and the FL (Lundberg 2010).

\subsection{Correlations between the measures}

First, the internal relations found between the FL_Total (aggregate score), FL_Receptive, and FL_productive were found to be significant, with coefficients ranging from .66, to .96, indicating the internal validity of the tests.

The aggregate FL score correlated strongly with Nonce_Gr. ( $r=.40$, $p<.01$ ), confirming previous findings that demonstrate a link between the loop and FL vocabulary learning (Masoura \& Gathercole 1999; Maбov́pa, Gathercole \& M $\alpha \alpha \mu \pi \lambda \dot{\varepsilon} \kappa o v$ 2004). It also associated with Listening Recall $(r=.36 p<.05)$, indicating the relation between CWM and FL vocabulary acquisition (St. Clair-Thompson \& Gathercole 2006).

Under closer examination, FL comprehension and production shared stronger to more moderate associations with both PSTM and CWM. FL Receptive correlated with Nonce_Gr. $(r=.42)$, Nonce_Eng. $(r=.33)$, and Listening Recall $(r=.44)$. This last finding suggests the direct involvement of CWM in the regulation of attention during FL comprehension (Kormos \& Sáfár 2008). FL production correlated with Listening Recall $(r=.42)$ 
and Nonce_Gr. $(r=.41)$, indicating the involvement of both PSTM and CWM when children attempt to produce language in the FL. This is natural, however, as this task at this early stage of FLL poses high attentional demands on learners who only possess limited language resources (Kormos \& Sáfár 2008).

The fact that both comprehension and production shared strong links with the Greek-sounding nonword repetition task may be interpreted in two ways. First, that FL performance in young learners is supported by a language-general phonological loop process (Andersson 2010; Maбoúpa,

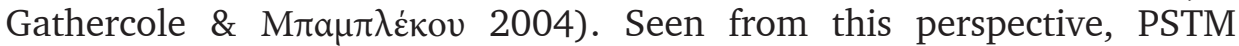
serves as the foundation for FLL (Cheung 1996; Sparks \& Ganschow 1991, 2001), supports memory performance and facilitates the ease with which learners acquire new lexical material (Baddeley, Gathercole \& Papagno 1998; Gathercole \& Adams 1994; Masoura \& Gathercole 1999;

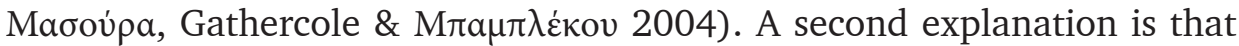
participants, by means of their central executive, resort to their LTM phonological representations of their L1, i.e. the language to which they are phonologically more sensitive, which holds better-quality or longerlasting phonological traces and as such they are consequently easier to repeat (Gathercole 1998; Gathercole et al. 1997; Maбoúpa, Gathercole \& M $\pi \alpha \mu \pi \lambda \dot{\varepsilon}$ kov 2004; Morra \& Camba 2009). This, according to Masoura and Gathercole (1999) is particularly evident in the initial stages of FLL. The findings align with previous ones, that have established the reciprocal relation of STM and LTM between the ages of 5 and 8 (Gathercole et al. 1992), where the capacity of the loop promotes the learning of the new phonological patterns of the foreign words, while existing phonological knowledge of the L1 supplements the loop and influences the ease with which learners retain lexical sequences in the phonological store.

\subsection{Stepwise regressions}

We then examined whether overall performance in the FL (FL_Voc._Total) or the two skills separately, comprehension and production could be predicted by PSTM and CWM.

When the aggregate FL score was the dependent variable, PSTM was a stronger predictor (Nonce_Gr., 14\%, F(1,45) = 8.510; $p<.01$ ) than CWM (Listening Recall, $11,3 \%, \overline{\mathrm{F}}(1,45)=6.835 ; p<.05)$. This suggests that in order to perform well in the vocabulary test the learners relied on the loop 
for the temporary storage of the phonological representations of the novel words and on their central executive for the coordination and execution of the multiple processing required during the FLL process. These findings align with those of Andersson (2010) who found an overall significant contribution of the two constructs (27\%) to FL comprehension in 9- to 10year-old Swedish learners of EFL. In Service (1992) a similar significant level of prediction (19\%) also emerged between nonword repetition scores and FL vocabulary learning. Kormos and Sáfár (2008) found an even stronger association (30.25\%) between CWM and FL proficiency, but with older learners (15- to 16-year-olds).

When FL comprehension and production were examined separately, CWM (Listening Recall) proved to be a stronger predictor than PSTM (Nonce_Gr.). When we entered FL comprehension into the analysis, CWM had a slightly greater predictive value $(17.7 \%)$ than PSTM (16\%). The same picture emerged with FL production, where CWM explained $15.8 \%$ of the variance, compared to the $15 \%$ of PSTM. This suggests that speaking in the FL poses high attentional demands on learners (Kormos \& Sáfár 2008). Since our participants were not yet literate in the FL, it is reasonable to assume that they relied heavily on their WM resources, the loop and the central executive, to encode the incoming FL information. With experience and practice this reliance is expected to gradually decrease over the years, when the FL processing will become more automatic and less effortful (Andersson 2010).

The findings confirm Kormos and Sáfár (2008), who argued that in the early stages of instructed FLL, CWM plays a more decisive role than PSTM, serving as a bottleneck in the acquisition of L2 skills; at more advanced stages, its capacity allows for the storage of verbal material in WM and the acquisition of an even wider repertoire of words and expressions.

To conclude, the findings corroborate previous ones with respect to PSTM and its close link to FLL (Alexiou 2005; Cheung 1996), while they establish a new, interesting and more powerful relation between the central executive and FL vocabulary learning. Our hypothesis was fully confirmed, with CWM being a stronger predictor of FL comprehension and production than PSTM. The large proportion of the variance in FL performance that was left unidentified suggests that FLL is a rather multidimensional process and remains highly subject to multiple other variables that were mentioned in the beginning of this article. 


\section{Concluding remarks}

The present study examined whether at a very early stage of FLL, apart from the often reported phonological loop, the mechanism of WM that is responsible for the allocation of attention, can also explain FL vocabulary learning. The findings indicate the active role of the central executive from the earliest stages of this process; this is important, since, in addition to directing attention, the central executive performs various other highlevel regulatory executive functions such as planning actions, solving problems and reasoning logically (Baddeley 1986; Kimberg, D'Esposito \& Farah 1997); as such, it may determine the learning potential of young children.

Regarding the FL performance of participants, the study confirmed that comprehension and production are two distinct processes that follow different trajectories; the latter is more arduous and takes more time to emerge than the former. Although the FL programme followed by the experimental school was intensive, we should keep in mind the following:

a) two years of FL exposure is a rather short period as the relevant literature suggests; in incidental vocabulary learning, learners need to encounter novel vocabulary in context multiple times before sizable gains emerge (Webb 2007), b) literacy in the FL, which can accelerate FL performance (Johnstone 2009) was still absent at the time of testing, c) children as young as these, have not yet developed the full and complex range of their learning strategies (Cole \& Cole 2001), to be able to further support this process. Hence, the results primarily reveal the vital contribution of critical cognitive skills to early FL vocabulary growth and not the FL competence of the young learners that is still developing.

\section{References}

Adams, A. M. and S. E. Gathercole (1996). Phonological Working Memory and Spoken Language Development in Young Children. The Quarterly Journal of Experimental Psychology, 49A(1), 216-233.

Alexiou, T. (2005). "Cognitive Development, Aptitude and Language Learning in Greek Young Learners". Doctoral dissertation, University of Wales, Swansea. 
Alloway, T. P. (2006). How Does Working Memory Work in the Classroom? Educational Research and Reviews, 1(4), 134-139.

Alloway, T. P. and R. G. Alloway (2010). Investigating the Predictive Roles of Working Memory and IQ in Academic Attainment. Journal of Experimental Child Psychology, 106, 20-29.

Alloway, T. P. et al. (2004). A Structural Analysis of Working Memory and Related Cognitive Skills in Young Children. Journal of Experimental Child Psychology, 87, 85-106.

Andersson, U. (2010). The Contribution of Working Memory Capacity to Foreign Language Comprehension in Children. Memory, 18(4), 458-472.

Archibald, L. M. and S. E. Gathercole (2006). Nonword Repetition: A Comparison of Tests. Journal of Speech, Language and Hearing Research, 49, 970-983.

Asher, J. (1982). Learning Another Language Through Actions: The Complete Teachers' Guidebook. Los Gatos/California: Sky Oaks Productions.

Baddeley, A. D. (1986). Working Memory. Oxford: Oxford University Press.

Baddeley, A. D. (1996). Exploring the Central Executive. The Quarterly Journal of Experimental Psychology, 49A(1), 5-28.

Baddeley, A. D. (2000). The Episodic Buffer: A New Component of Working Memory? Trends in Cognitive Sciences, 4(11), 417-423.

Baddeley, A. D. (2003). Working Memory and Language: An Overview. Journal of Communication Disorders, 36, 189-208.

Baddeley, A. D., Gathercole, S. E. and C. Papagno (1998). The Phonological Loop as a Language Learning Device. Psychological Review, 105, 158-173.

Baddeley, A. D. and G. Hitch (1974). Working Memory. In: G. Bower (ed.), The Psychology of Learning and Motivation (Vol. 8), New York: Academic Press, 47-89.

Baddeley, A. D., Thomson, N. and M. Buchanan (1975). Word Length and the Structure of Short-Term Memory. Journal of Verbal Learning and Verbal Behaviour, 14, 575-589.

Beveridge, M., Jarrold, C. and E. Pettit (2002). An Experimental Approach to Executive Fingerprinting in Young Children. Infant and Child Development, 11, 107-123.

Bialystok, E. (1981). The Role of Conscious Strategies in Second Language Proficiency. Modern Language Journal, 65(1), 24-35.

Bialystok, E. (1997). The Structure of Age: In Search of Barriers to Second Language Acquisition. Second Language Research, 13(2), 116-137. 
Bley-Vroman, R. (1990). The Logical Problem of Foreign Language Learning. Linguistic Analysis, 201(2), 3-49.

Blondin, C. et al. (1998). Foreign Languages in Primary and Pre-School Education: Context and Outcomes. A Review of Recent Research Within the European Union. London: CILT.

Carroll, J. B. (1981). Twenty-Five Years of Research on Foreign Language Aptitude. In: K. C. Diller (ed.), Individual Differences and Universals in Language Learning Aptitude, Rowley/Mass.: Newbury House, 83-118.

Cenoz, J. (2003). The Influence of Age on the Acquisition of English: General Proficiency, Attitudes and Code Mixing. In: M. P. García Mayo and M. L. García Lecumberri (eds.), Age and the Acquisition of English as a Foreign Language, Clevedon: Multilingual Matters, 77-93.

Cheung, H. (1996). Nonword Span as a Unique Predictor of SecondLanguage Vocabulary Learning. Developmental Psychology, 3, 867-873.

Chomsky, N. (2005). Universals of Human Nature. Psychotherapy and Psychomatics, 74, 263-268.

Cole, M. and S. R. Cole (2001). The Development of Children ( $4^{\text {th }}$ ed.). New York: Worth Publishers.

Conway, R. A. et al. (2005). Working Memory Span Tasks: A Methodological Review and User's Guide. Psychonomic Bulletin and Review, 12(5), 769-786.

Cummins, J. (1984). Bilingualism and Special Education: Issues in Assessment and Pedagogy. Clevedon: Multilingual Matters.

Dalton-Puffer, C. (2008). Outcomes and Processes in Content and Language Integrated Learning (CLIL): Current Research from Europe. In: W. Delanoy et al. (eds.), Future Perspectives for English Language Teaching, Heidelberg: Carl Winteer, 139-157.

Daneman, M. and P. A. Carpenter (1980). Individual Differences in Working Memory and Reading. Journal of Verbal Learning and Verbal Behaviour, 19, 450-466.

Dörnyei, Z. (2005). The Psychology of the Language Learner. Individual Differences in Second Language Acquisition. Mahwah, NJ: Lawrence Erlbaum.

Dörneyi, Z. and P. Skehan (2003). Individual Differences in Second Language Learning. In: C. J. Doughty et al. (eds.), The Handbook of Second Language Acquisition, Oxford: Blackwell Publishing, 589-630.

Ehrman, M. E., Leaver, B. L. and R. L. Oxford (2003). A Brief Overview of Individual Differences in Second Language Learning. System, 31, 313-330. 
Ellis, R. (1994). The Study of Second Language Acquisition. Oxford: Oxford University Press.

Ellis, R. (2003). The Study of Second Language Acquisition (10 ${ }^{\text {th }}$ impression ed.). Oxford: Oxford University Press.

The Eurydice Report (2012). Key Data on Teaching Languages at School in Europe. Brussels: EACEA.

García Lecumberri, M. L. and F. Gallardo (2003). English FL Sounds in School Learners of Different Ages. In: M. P. García Mayo and M. L. García Lecumberri (eds.), Age and the Acquisition of English as a Foreign Language, Clevedon: Multilingual Matters, 115-135.

García Mayo, M. P. (2003). Age, Length of Exposure and Grammaticality Judgments in the Acquisition of English as a Foreign Language. In: M. P. García Mayo and M. L. García Lecumberri (eds.), Age and the Acquisition of English as a Foreign Language, Clevedon: Multilingual Matters, 94-114.

Gardner, R. C. (1990). Attitudes, Motivation, and Personality as Predictors of Success in Foreign Language Learning. In: T. S. Parry et al. (eds.), Language Aptitude Revisited, Englewood Cliffs/NJ: Prentice Hall, 179221.

Gass, S. M. and A. Mackey (2007). Input, Interaction, and Output in Second Language Acquisition. In: B. VanPatten et al. (eds.), Theories in Second Language Acquisition, Mahwah/NJ: Lawrence Erlbaum, 175-199.

Gathercole, S. E. (1998). The Development of Memory. Journal of Child Psychology, 39(1), 3-27.

Gathercole, S. E. (1999). Cognitive Approaches to the Development of Short-Term Memory. Trends in Cognitive Sciences, 3, 410-419.

Gathercole, S. E. and A. Adams (1994). Children's Phonological Working Memory: Contributions of Long-Term Knowledge and Rehearsal. Journal of Memory and Language, 33(5), 672-688.

Gathercole, S. E. and T. P. Alloway (2008). Working Memory and Classroom Learning. In: K. Thurman et al. (eds.), Cognitive Development in K-3 Classroom Learning: Research Applications, Mahwah/NJ: Lawrence Erlbaum, 15-38.

Gathercole, S. E. and A. D. Baddeley (1993). Working Memory and Language. Hillsdale/NJ: Lawrence Erlbaum.

Gathercole, S. E. and A. D. Baddeley (1996). The Children's Test of Nonword Repetition. San Diego/CA: The Psychological Corporation. 
Gathercole, S. E., Brown. L. and S. J. Pickering (2003). Working Memory Assessments at School Entry as Longitudinal Predictors of National Curriculum Attainment Levels. Educational and Child Psychology, 20(3), 109-122.

Gathercole, S. E. and S. J. Pickering (2000a). Working Memory Deficits in Children with Low Achievements in the National Curriculum at 7 Years of Age. British Journal of Educational Psychology, 70, 177-194.

Gathercole, S. E. and S. J. Pickering (2000b). Assessment of Working Memory in Six- and Seven-Year-Old Children. Journal of Educational Psychology, 92(2), 377-390.

Gathercole, S. E. et al. (1992). Phonological Memory and Vocabulary Development During the Early School Years: A Longitudinal Study. Developmental Psychology, 28(5), 887-898.

Gathercole, S. E. et al. (1997). Phonological Short-Term Memory and New Word Learning in Children. Developmental Psychology, 33, 966-979.

Gathercole, S. E. et al. (2004). The Structure of Working Memory from 4 to 15 Years of Age. Developmental Psychology, 40(2), 177-190.

Goorhuis-Brouwer, S. and K. De Bot (2010). Impact of Early English Language Teaching on L1 and L2 Development in Children in Dutch Schools. International Journal of Bilingualism, 14(3), 289-302.

Hummel, K. M. and L. M. French (2010). Phonological Memory and Implications for the Second Language Classroom. The Canadian Modern Language Review, 66(3), 371-391.

Johnson, J. S. and E. L. Newport (1989). Critical Period Effects in Second Language Learning: The Influence of Maturational State on the Acquisition of English as a Second Language. Cognitive Psychology, 21, 60-99.

Johnstone, R. (2009). An Early Start: What Are the Key Conditions for Generalized Success? In: J. Enever et al. (eds.), Young Learner English Language Policy and Implementation: International Perspectives, Reading/ UK: Garnet Publishing, 31-42.

Kimberg, D. Y., D’Esposito, M. and M. J. Farah (1997). Cognitive Functions in the Prefrontal Cortex - Working Memory and Executive Control. Directions in Psychological Science, 6(6), 185-192.

Kormos, J. and A. Sáfár (2008). Phonological Short-Term Memory, Working Memory and Foreign Language Performance in Intensive Language Learning. Bilingualism: Language and Cognition, 11(2), 261-271. 
Krashen, S. D. (1985). The Input Hypothesis: Issues and Implications. London/New York: Longman.

Krashen, S. D., Long, M. H. and R. C. Scarcella (1982). Age, Rate, and Eventual Attainment in Second Language Acquisition. In: S. D. Krashen et al. (eds.), Child-Adult Differences in Second Language Acquisition, Rowley/Mass.: Newbury House, 161-172.

Krashen, S. D. and T. Terrell (1983). The Natural Approach: Language Acquisition in the Classroom. Hayward/California: Alemany Press.

Lehto, J. E. et al. (2003). Dimensions of Executive Functioning: Evidence from Children. British Journal of Developmental Psychology, 21, 59-80.

Lundberg, G. (2010). The Significance of the Teacher's Role in Early Language Learning. Early Language Learning in Europe. (15 March 2016) < http://www.ellieresearch.eu/docs/6>.

Lundberg, G. and E. Lindgren (2008). Tracing Young Learners' Foreign Language Development. Paper presented at the British Association for Applied Linguistics Conference. Swansea, UK.

Mackey, A. et al. (2002). Individual Differences in Working Memory, Noticing of Interactional Feedback and L2 Development. In: P. Robinson (ed.), Individual Differences and Instructed Language Learning, Amsterdam/ Philadelphia: John Benjamins, 181-209.

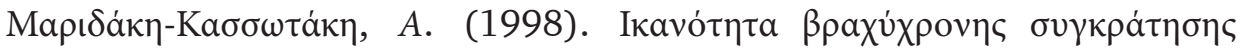

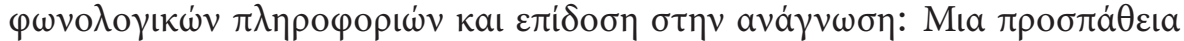

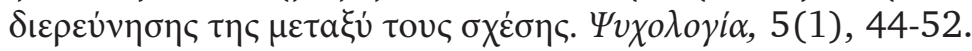

Maridaki-Kassotaki, K. (2002). The Relation Between Phonological Memory Skills and Reading Ability in Greek-Speaking Children: Can Training of Phonological Memory Contribute to Reading Development? European Journal of Psychology of Education, 17(1), 63-73.

Masoura, E. V. and S. E. Gathercole (1999). Phonological Short-Term Memory and Foreign Language Learning. International Journal of Psychology, 34(5/6), 383-388.

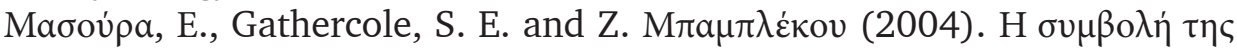

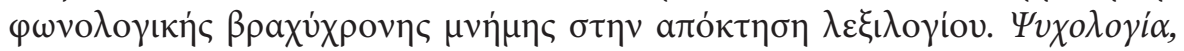
11(3), 341-355.

Mattheoudakis, M., Alexiou, T. and C. Laskaridou (2014). To CLIL or not to CLIL? The Case of the 3rd Experimental Primary School in Evosmos. In: N. Lavidas et al. (eds.), Selected Papers from the 20th International Symposium of Theoretical and Applied Linguistics, Versita Publications, 215-234. 
McLaughlin, B. (1984). Second-Language Acquisition in Childhood: Preschool Children ( $2^{\text {nd }}$ ed., Vol. 1). Hillsdale/NJ: Lawrence Erlbaum.

McLaughlin, B. (1990). Restructuring. Applied Linguistics, 11, 113-128.

Mihaljevic Djigunovic, J. (2009). Impact of Learning Conditions on Young FL Learners' Motivation. In: M. Nikolov (ed.), Early Learning of Modern Foreign Languages. Processes and Outcomes, Bristol/Buffalo/Toronto: Multilingual Matters, 75-89.

Mihaljevic Djigunovic, J. and S. L. Krevelj (2009). Instructed Early SLA - Development of Attitudes. SRAZ LIV, 137-156.

Miyake, A. et al. (2000). The Unity and Diversity of Executive Functions and Their Contributions to Complex Frontal Lobe Tasks: A Latent Variables Analysis. Cognitive Psychology, 41, 49-100.

Monette, S., Bigras M. and M. C. Guay (2011). The Role of the Executive Functions in School Achievement at the End of Grade 1. Journal of Experimental Child Psychology, 109, 158-173.

Morra, S. and R. Camba (2009). Vocabulary Learning in Primary School Children: Working Memory and Long-Term Components. Journal of Experimental Child Psychology, 104, 156-178.

Muñoz, C. (2003). Variation in Oral Skills Development and Age of Onset. In: M. P. García Mayo and M. L. García Lecumberri (eds.), Age and the Acquisition of English as a Foreign Language, Clevedon: Multilingual Matters, 161-181.

Muñoz, C. (2006). The Effects of Age on Foreign Language Learning: The BAF Project. In: C. Muñoz (ed.), Age and Rate of Foreign Language Learning, Clevedon: Multilingual Matters, 1-40.

Muñoz, C. (2010). On How Age Affects Foreign Language Learning. Advances in Research on Language Acquisition and Teaching. Selected Papers, Greek Applied Linguistics Association, 39-49.

Nevo, E. and Z. Breznitz (2011). Assessment of Working Memory Components at 6 Years of Age as Predictors of Reading Achievements a Year Later. Journal of Experimental Child Psychology, 109, 73-90.

Nikolov, M. (2009a). Introduction: Early Learning of Modern Foreign Languages. In: M. Nikolov (ed.), Early Learning of Modern Foreign Languages, Bristol: Multilingual Matters, xiii-xvi.

Nikolov, M. (ed.). (2009b). The Age Factor and Early Language Learning. Berlin, Germany: Mouton de Gruyter.

Nikolov, M. and J. Mihaljevic Djigunovic (2006). Recent Research on Age, Second Language Acquisition, and Early Foreign Language Learning. Annual Review of Applied Linguistics, 26, 234-260. 
Nikolov, M. and J. Mihaljevic Djigunovic (2011). All Shades of Every Colour: An Overview of Early Teaching and Learning of Foreign Languages. Annual Review of Applied Linguistics, 31, 95-119.

Okalidou, A. et al. (2011). Adapting a Receptive Vocabulary Test for Preschool-Aged Greek-Speaking Children. International Journal of Language and Communication Disorders, 46(1), 95-107.

Oxford, R. L. (1989). Use of Language Learning Strategies: A Synthesis of Studies with Implications for Strategy Training. System, 17(2), 235247.

Papagno, C., Valentine, T. and A. D. Baddeley (1991). Phonological ShortTerm Memory and Foreign-Language Vocabulary Learning. Journal of Memory and Language, 30(3), 331-347.

Pinter, A. (2011). Children Learning Second Languages. New York: Palgrave Macmillan.

Randall, M. (2007). Memory, Psychology and Second Language Learning. Amsterdam/Philadelphia: John Benjamins.

Robinson, P. (2002). Effects of Individual Differences in Intelligence, Aptitude and Working Memory on Adult Incidental SLA: A Replication and Extension of Reber, Walkenfeld and Hernstadt. In: P. Robinson (ed.), Individual Differences And Instructed Language Learning, Amsterdam/ Philadelphia: John Benjamins, 211-266.

Sáfár, A. and J. Kormos (2008). Revisiting Problems with Foreign Language Aptitude. IRAL, 46, 113-136.

Sawyer, M. and L. Ranta (2001). Aptitude, Individual Differences, and Instructional Design. In: P. Robinson (ed.), Cognition and Second Language Instruction, Cambridge: Cambridge University Press, 319353.

Schmidt, R. (2001). Attention. In: P. Robinson (ed.), Cognition and Second Language Acquisition, New York: Cambridge University Press, 3-32.

Service, E. (1992). Phonology, Working Memory, and Foreign-Language Learning. The Quarterly Journal of Experimental Psychology, 45A(1), 21-50.

Singleton, D. and L. Ryan (2004). Language Acquisition: The Age Factor (2 ${ }^{\text {nd }}$ ed.). Clevedon/Buffalo/Toronto: Multilingual Matters.

Sparks, R. L. and L. Ganschow (1991). Foreign Language Learning Differences: Affective or Native Language Aptitude Differences? The Modern Language Journal, 75(1), 3-16. 
Sparks, R. L. and L. Ganschow (2001). Aptitude for Learning a Foreign Language. Annual Review Of Applied Linguistics, 21, 90-111.

Stavrakaki, S. and I. M. Tsimpli (2000). Diagnostic Verbal IQ Test for Greek Preschool and School Age Children: Standardization, Statistical Analysis, Psychometric Properties. The Proceedings of the 8th Symposium of the Panhellenic Association of Logopedists. Athens: Ellinika Grammata, 95-106.

St. Clair-Thompson, H. L. and S. E. Gathercole (2006). Executive Functions and Achievements in School: Shifting, Updating, Inhibition, and Working Memory. The Quarterly Journal of Experimental Psychology, 59(4), 745-759.

Szpotowicz, M. (2010). Variability in Young Learners' Vocabulary Production in Instructed Contexts. Early Language Learning in Europe. (15 March 2016) < http://www.ellieresearch.eu/docs/10>.

Terrell, T. D. (1977). A Natural Approach to Second Language Acquisition and Learning. The Modern Language Journal, 61(7), 325-337.

Wattendorf, E. and J. Festman (2008). Images of the Multilingual Brain: The Effect of Age of Second Language Acquisition. Annual Review of Applied Linguistics, 28, 3-24.

Webb, S. (2007). The Effects of Repetition on Vocabulary Knowledge. Applied Linguistics, 28(1), 46-65.

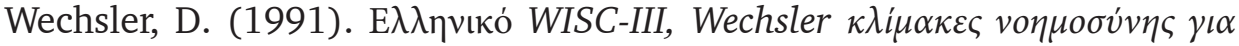

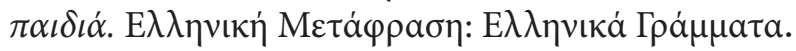

Wiebe, S. A. et al. (2011). The Structure of Executive Function in 3-YearOlds. Journal of Experimental Child Psychology, 108, 436-452.

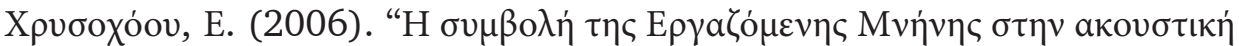

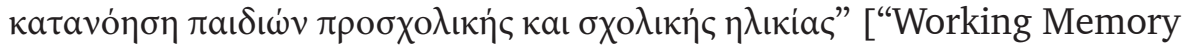
Contributions to Young Children's Listening Comprehension"].

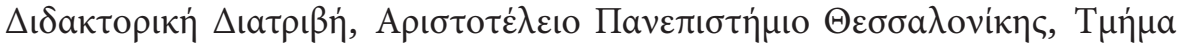

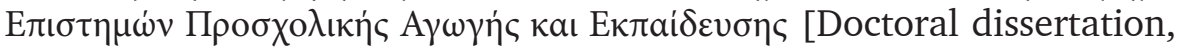
Aristotle University of Thessaloniki, School of Early Childhood Education]. 


\section{APPENDIX 1: THE RECEPTIVE TEST_SAMPLE SLIDES}

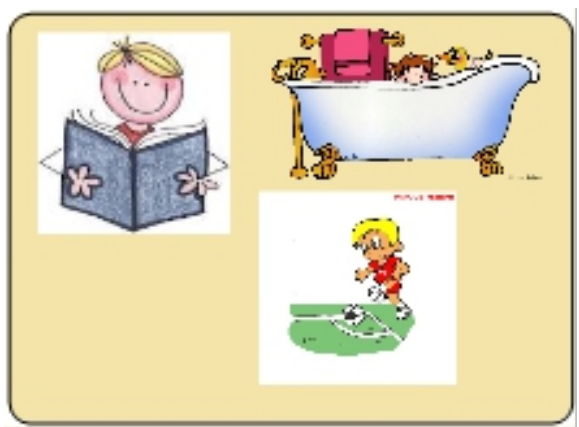

Slide 1: The boy is having a bath

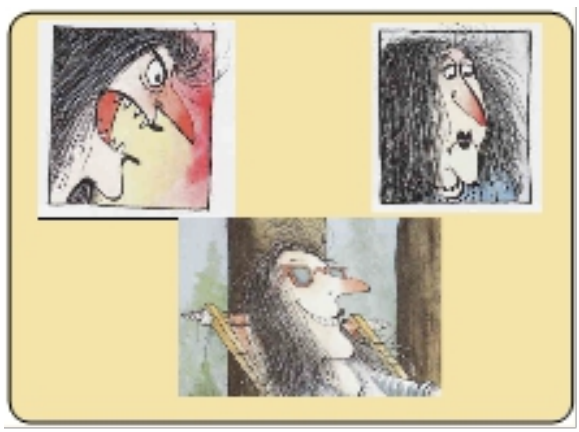

Slide 2: Winnie is angry

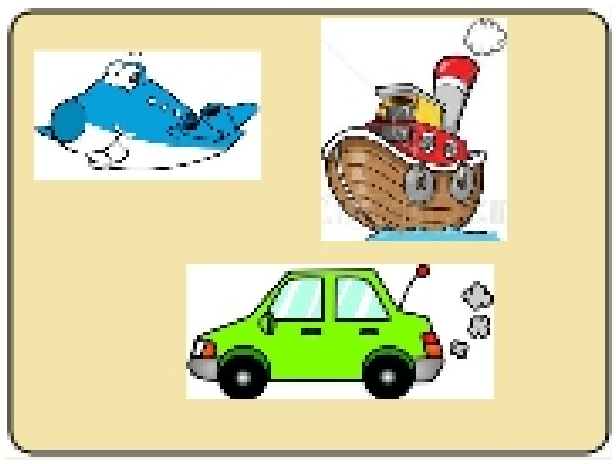

Slide 3: Show me the car 


\section{APPENDIX 2: THE PRODUCTIVE TEST_SAMPLE SLIDES}

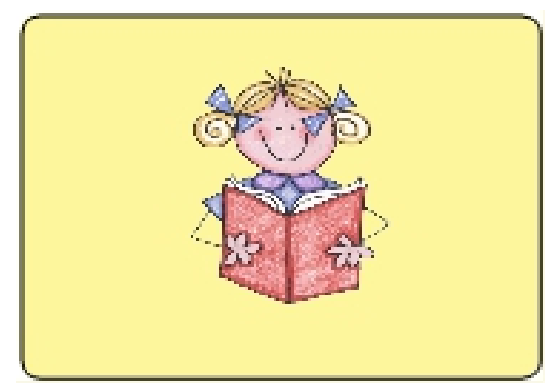

Slide 1: What is the girl doing? (reading a book)

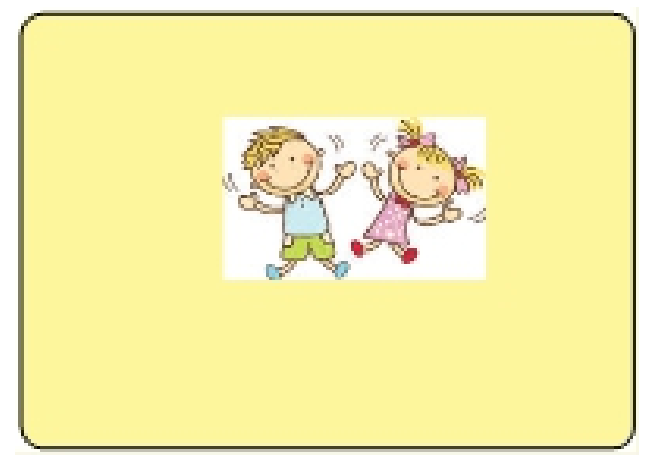

Slide 2: The boy and the girl are very ... (happy)

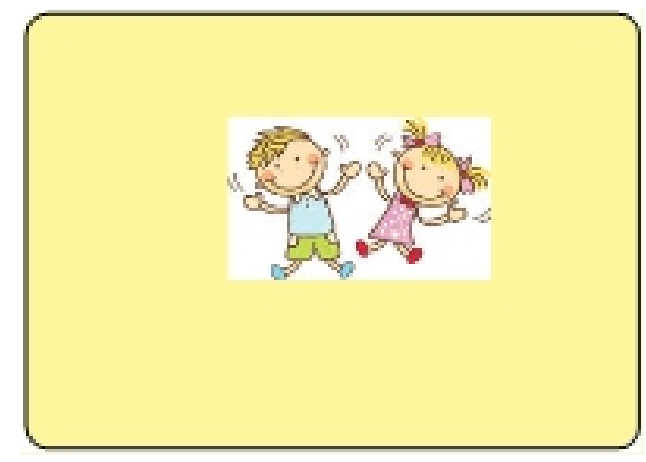

Slide 3: This is an ... (airplane or plane) 


\section{Tables}

Table 1. Descriptive Statistics - Mean and Standard Deviation (SD)

\begin{tabular}{|l|c|c|}
\hline \multicolumn{1}{|c|}{ Tasks } & Mean & SD \\
\hline FL_Voc._Total & 24.69 & 5.43 \\
\hline FL_Receptive & 12.82 & 1.73 \\
\hline FL_Productive & 12.15 & 3.58 \\
\hline Digit recall_Forward & 7.05 & 1.46 \\
\hline Nonce_Gr. & 34.99 & 3.59 \\
\hline Nonce_Eng. & 28.51 & 3.96 \\
\hline Digit recall_Backwards & 4.31 & 1.10 \\
\hline Listening Recall & 7.05 & 3.04 \\
\hline
\end{tabular}

Table 2. Participants' combined performance in the two FL tests

\begin{tabular}{|c|c|c|c|c|c|c|}
\hline & \multicolumn{3}{|c|}{ Score Productive } & \multirow{2}{*}{ Total } \\
\hline & & & 39 & $10-14$ & $15-19$ & \\
\hline \multirow{6}{*}{$\begin{array}{c}\text { Score } \\
\text { Receptive }\end{array}$} & \multirow{2}{*}{37} & Count & 4 & 0 & 0 & 4 \\
\hline & & $\%$ of Total & $8.2 \%$ & $.0 \%$ & $.0 \%$ & $8.2 \%$ \\
\hline & \multirow{2}{*}{$8-11$} & Count & 9 & 2 & 0 & 11 \\
\hline & & $\%$ of Total & $18.4 \%$ & $4.1 \%$ & $.0 \%$ & $22.4 \%$ \\
\hline & \multirow{2}{*}{$12-15$} & Count & 2 & 16 & 16 & 34 \\
\hline & & $\%$ of Total & $4.1 \%$ & $32.7 \%$ & $32.7 \%$ & $69.4 \%$ \\
\hline \multirow[t]{2}{*}{ Total } & & Count & 15 & 18 & 16 & 49 \\
\hline & & $\%$ of Total & $30.6 \%$ & $36.7 \%$ & $32.7 \%$ & $100.0 \%$ \\
\hline
\end{tabular}




\section{Figures}

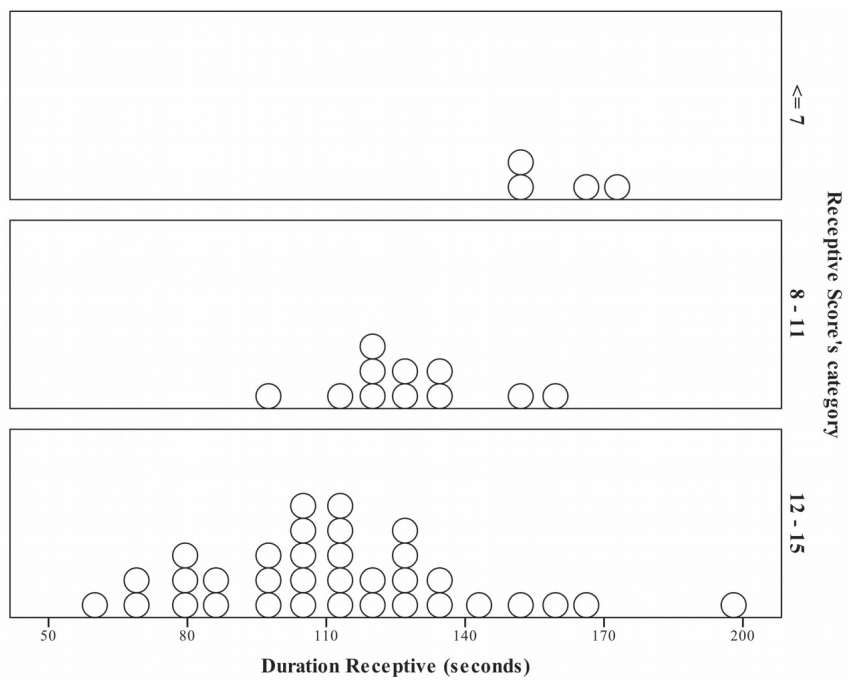

Figure 1: FL_Receptive: Time duration and score
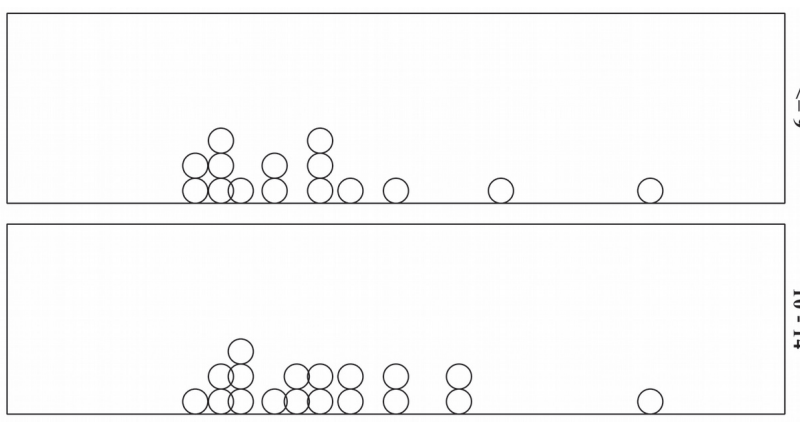

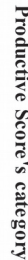

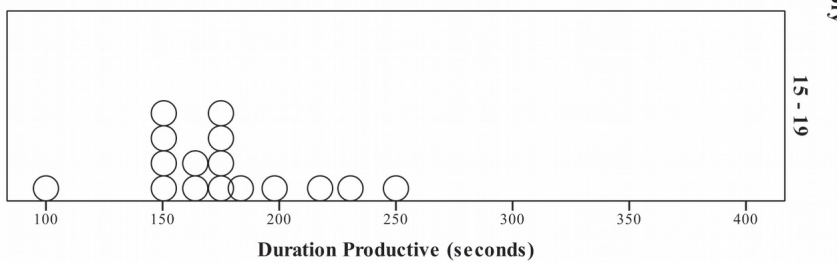

Figure 2: FL_Productive: Time duration and score

Received: 1 August 2018

Accepted for publication: 28 December 2018 
Лија Евстатиади

\section{РАНО УЧЕЊЕ СТРАНОГ ЈЕЗИКА: ИНТЕНЗИВНА ИЗЛОЖЕНОСТ, РАЗВОЈ ЛЕКСИКЕ И КОГНИТИВНЕ ВЕШТИНЕ УКЉУЧЕНЕ У ТАЈ ПРОЦЕС}

\section{Сажетак}

Овај рад бави се развојем лексике и когнитивним основама тог развоја код 49 младих ученика грчке националности (просечне старости 7 година и 8 месеци), након што су током две године били интензивно изложени енглеском као другом језику. Подаци су прикупљени у експерименталној школи за учење енглеског језика у Солуну, у којој се примењују иновативне методе наставе. Тестирање је обављено у другом разреду, када су учесници били довољно изложени другом језику (у просеку 300 сати). Мерили смо лексику другог језика (разумевање и продукцију) и радну меморију, нарочито памћење везано за фонологију, пошто је оно уско повезано са раним развојем лексике другог језика (Gathercole \& Alloway 2008). Пошто је природа комуникативног приступа настави другог језика захтевна у контексту одржавања пажње, такође смо се бавили улогом централног извршиоца радне меморије током раног развоја лексике страног језика.

Кључне речи: рани развој лексике страног језика, интегрисано учење садржаја и језика (CLIL), фонолошко краткорочно памћење, централни извршилац 